\title{
Wdzięczność i ostrzeżenie? Rozważanie metodologiczne o nowej próbie bilansu historiografii PRL
}

Stobiecki Rafał (2020), Historiografia PRL. Zamiast podręcznika, Wydawnictwo Uniwersytetu Łódzkiego, Łódź.

\begin{abstract}
Kluczowego znaczenia nabiera tu pytanie: $w$ jaki sposób chcemy „rozliczać” się z dziedzictwem PRLowskiej historiografii? Jakie formuly i konwencje powinny nam towarzyszyć? Sązę, że powinna nam być bliska perspektywa rozumiejąca.
\end{abstract}

(Stobiecki 2020: 18)

Najnowszą pracę Rafała Stobieckiego poświęconą historiografii PRL studiuję z perspektywy metodologa historii zainteresowanego sposobami poznawczego odnoszenia się do przeszłości i nastawieniami, z jakimi do niej podchodzimy².

1 Książka składa się ze wstępu, zakończenia oraz sześciu rozdziałów, w których Autor omawia kolejne okresy rozwoju historiografii PRL, wyróżniając (I) okres początku budowy nowej rzeczywistości, (II) okres stalinizmu, (III) przełom październikowy i destalinizację, (IV) historiografię w latach sześćdziesiątych, (V) historiografię w dekadzie Gierka (w której Autor akcentuje powstanie tak zwanego drugiego obiegu wydawniczego) oraz (VI) historiografię w latach osiemdziesiątych. W kolejnych rozdziałach konsekwentnie analizowane są przemiany wymiaru instytucjonalnego historiografii, spory metodologiczne oraz modyfikacje dotyczące reprezentacji przeszłości. Momentami, w których 
Inicjując poniższe uwagi interpretacyjne, chciałbym zasygnalizować perspektywę, z której analizuję książkę Stobieckiego. Niewątpliwie jest to perspektywa pod względem teoretycznym, przynajmniej w pewnej mierze, zewnętrzna w stosunku do projektu Autora, a w szczególności zewnętrzna w odniesieniu do założeń metodologicznych tego projektu. Tym, co mnie interesuje, nie jest historiografia PRL jako taka, tylko to, w jakim zakresie odniesiony do niej sposób jej interpretowania przyczynia się do wygenerowania ciągłości lub zerwania w toczącej się historii po zakończeniu okresu PRL.

Mówiąc w największym skrócie: sądzę, że jeśli nasza wykładnia przeszłości ukazuje w niej określoną walkę, określony spór, w którym można wykazać ciemiężących i ciemiężonych, nadzorujących i nadzorowanych, zwycięzców i przegranych, sprawców i ofiary, to dzisiejsza interwencja poznawcza (na przykład poprzez opracowanie obrazu historiografii PRL) nie tylko oznacza wytwarzanie reprezentacji przeszłości, lecz również posiada wymiar potwierdzania lub kwestionowania zaistniałego w przeszłości rezultatu rejestrowanych przez nas (w owej interwencji poznawczej) walki bądź sporu. Badanie historiograficzne generuje pewną formę kontynuacji lub dyskontynuacji przeszłości, której reprezentację wytwarza. Nie jest ono zatem neutralne, gdyż potwierdza lub podważa bilans minionych zwycięstw i porażek, minionych zdobyczy i upokorzeń, minionych, jak skłonni jesteśmy - niekiedy przedwcześnie - o nich myśleć, rozstrzygnięć sporów, które osadziły się na ścieżce czasu, tworząc przebieg realnej historii ${ }^{2}$.

skupiają się cechy dystynktywne historiografii polskiej w wyróżnionych okresach, stały się w wykładzie Autora wystąpienia historyków podczas Powszechnych Zjazdów Historyków organizowanych przez Polskie Towarzystwo Historyczne.

Rafał Stobiecki jest profesorem zwyczajnym w Instytucie Historii Uniwersytetu Łódzkiego, kierownikiem Katedry Historii Historiografii i Nauk Pomocniczych Historii. Jest uczniem prof. Krystyny Śreniowskiej oraz prof. Andrzeja Feliksa Grabskiego. Jego zainteresowania badawcze obejmują dzieje polskiej i powszechnej myśli historycznej w XIX i XX wieku. Opublikował m.in.: Historia pod nadzorem. Spory o nowy model historii w Polsce - druga połowa lat czterdziestych - początek lat pięćdziesiątych, Wydawnictwo Uniwersytetu Łódzkiego, Łódź 1993; Bolszewizm a Historia. Próba rekonstrukcji bolszewickiej filozofii dziejów, Wydawnictwo Uniwersytetu Łódzkiego, Łódź 1998; Klio na wygnaniu. $Z$ dziejów polskiej historiografii na uchodźstwie w Wielkiej Brytanii po 1945 r. Wydawnictwo Poznańskie, Poznań 2005; Klio za wielka wodą. Polscy historycy w Stanach Zjednoczonych po 1945 roku, Instytut Pamięci Narodowej - Komisja Ścigania Zbrodni przeciwko Narodowi Polskiemu, Warszawa 2017.

2 Wskazywane w tym miejscu moje własne przeświadczenia i zainteresowania teoretyczne przybliżam i wyjaśniam niżej. 
W wielu miejscach pracy Autor sygnalizuje, że jego namysł nad historiografią PRL jest oparty na rozumieniu dwuznaczności relacji między nią a współczesnym „stanem posiadania” historiografii w Polsce. Z jednej bowiem strony, historiografia PRL powstawała w uwarunkowaniach należących do okresu w historii Polski zakończonego przed ponad 30 laty. Z drugiej jednak, nie zakończyło się oddziaływanie tamtego czasu na naszą współczesność badań historiograficznych. Oddziaływanie to sprawia, że historiografia PRL pozostaje naszą tradycją zarówno w znaczeniu dyskursu, o którym sądzimy, że z niego wyrastamy, że stanowi naszą genezę, że od niego pochodzimy, jak i w znaczeniu dziedzictwa obciążającego, które powinno zostać przezwyciężone i odsunięte w przeszłość 3 . Jeśli praca Stobieckiego stawia problem bilansu historiografii PRL, pewnego rozliczenia się z nią, to - ponieważ owa historiografia jest interpretowana jako tradycja żywa we współczesności - ów bilans minionego czasu posiada aspekt mniej lub bardziej krytycznego wglądu we współczesność badacza. Bilans przeszłości obecnej jako tradycja jest w pewnym swoim wymiarze refleksją nad współczesnością, w której jest obecny analizowany przez historyka historiografii przekaz przeszłości.

Autor wyraża szkicowaną tu ideę, wskazując, że jeśli nie uporamy się poznawczo z naszą przeszłością i nie oswoimy jej egzystencjalnie, „jutro nie odnajdziemy sensu w tym, co przeżywaliśmy dziś” (Stobiecki 2020: 11). Bilans przeszłości, rozumiany jako poznawcze uporanie się z nią i dzięki niemu oswojenie jej (egzystencjalne), jest w tej perspektywie warunkiem odnalezienia sensu naszego własnego doświadczenia tworzenia wiedzy historycznej w teraźniejszości, ujawnianego w jej retrospektywnych wykładniach i (zawsze prowizorycznych) podsumowaniach. Zatem historiografia PRL, jeśli należy do przeszłości, to rozumianej w czasie imperfectum. Należy bowiem do naszej przeszłości współczesnej, przeszłości obecnej, warunkującej zrozumiałość wytwarzających interpretację owej przeszłości dzisiejszych strategii interpretacyjnych.

3 „Historiografia PRL może być postrzegana jako tradycja grupowa, środowiskowa, w której partycypujemy jako kontynuatorzy dzieła naszych poprzedników” (Stobiecki 2020: 12); „Nawiązując do ustaleń Jerzego Szackiego, można powiedzieć, że współcześnie działający historycy reprezentują w stosunku do fenomenu tradycji historiograficznej okresu PRL dwa stanowiska - podmiotowe i przedmiotowe. Zwolennicy pierwszego $\mathrm{z}$ nich traktują dorobek historiograficzny tego okresu w kategoriach dziedzictwa ważnego z punktu widzenia współczesności, wymagającego krytycznego rozrachunku, często jako synonim antytradycji. Do innej argumentacji odwołują się ci, którzy chcieliby rozumieć ową tradycję historiograficzną w sensie przedmiotowym. Jest ona dla nich symbolem negatywnego doświadczenia, władzy przeszłości nad teraźniejszością, nieprzezwyciężonym traumatycznym przeżyciem kilku pokoleń polskich historyków" (Stobiecki 2020: 17-18). 
W jaki sposób zmierzać do dokonania bilansu historiografii okresu PRL? Rozumowanie Autora oparte jest na kilku zasadniczych założeniach, z których niektóre są wyeksplikowane w tekście wprost, a inne pozostają w nim obecne w sposób milczący.

Stobiecki pracuje w oparciu o szerokie rozumienie zakresu badań historii historiografii. Obejmuje nimi nie tylko „badania nad infrastrukturą nauki historycznej”, do których zalicza przeszłość instytucjonalnego wymiaru środowiska historyków, rozumianego jako zbiorowość prowadzących badania naukowe nad przeszłością, lecz również przemiany założeń metodologicznych, na których były oparte badania historyczne w okresie PRL oraz zasadnicze cechy reprezentacji przeszłości wypracowanych przez historiografię PRL (Stobiecki 2020: 9).

Powyższe założenie dotyczy zakresu tematycznego studium historii historiografii. Druga presupozycja książki wyrażona explicite dotyczy rozumienia terminu historiografia PRL, to znaczy tego, jakie dzieła i autorzy wchodzą w zakres rozważań wyznaczonych tym terminem. Podobnie jak w przypadku pierwszego kryterium, Autor optuje za szerokim rozumieniem branej pod uwagę kategorii, zaliczając do analizowanej historiografii prace historyków reprezentujących całą gamę postaw w stosunku do dążeń ideologii władzy, od badaczy włączających się w przemiany ustrojowe i ideologiczne lat 1945-1989, do nastawionych opozycyjnie wobec nich, niezależnie od tego, czy historiografia przez nich wytwarzana funkcjonowała w oficjalnym obiegu wydawniczym, pod presją cenzury, czy niezależnie od niego, w tak zwanym drugim obiegu (Stobiecki 2020: 11).

Wydaje się, że w pracy Stobieckiego najważniejsze jest pojęcie „postawy”, jaką przyjmowali historycy w stosunku do presji i nadzoru ze strony czynników państwowo-partyjnych (na temat „rachunku sumienia” historyków por. Stobiecki 2020: 14-15). Historiografia w okresie PRL była nadzorowana na różne sposoby przez agendy państwa i partii (nadzór jawny i tajny poprzez służby). W perspektywie Autora badania nad tak usytuowaną w życiu społeczno-politycznym historiografią powinny rejestrować różnorodność postaw historyków wobec dotyczącej ich presji. Strategia taka wydaje się naturalna. Znajduje potwierdzenie, z jednej strony, w postaci uchwytnych w źródłach historycznych wysiłków władzy zmierzającej do podporządkowania sobie historiografii i uczynienia jej jednym ze swoich narzędzi. Z drugiej, znajduje wsparcie w wypowiedziach historyków wspominających ów czas jako okres próby i trudnych wyborów, których stawką było uzyskanie miejsca w definiowanym w znacznej mierze przez państwo życiu społecznym i uniknięcie tym samym bezdomności oraz zachowanie własnej tożsamości, rozumianej jako wierność regułom uprawianej dyscypliny naukowej (Stobiecki 2020: 243). 
Autor interpretuje analizowane przez siebie postawy historyków jako pewien rodzaj gry z systemem o uzyskanie pozycji w przestrzeni społecznej, a także o zachowanie godności.

Wykorzystywane przez Stobieckiego pojęcie gry nawiązuje nie tylko do Czesława Miłosza rozważań o ketmanie (Stobiecki 2020: 22), lecz również do innych autorów, takich jak Stefan Kieniewicz (Stobiecki 2020: 15-16), Krystyna Kersten (dla której stawką gry w przypadku przegranej była wspomniana wyżej bezdomność), a także np. (spośród współczesnych) Janusz Goćkowski, który wyróżniał grę o przystosowanie się i grę o zachowanie tożsamości (Stobiecki 2020: 23). Postawa w grze podlega interpretacji przez historyka historiografii, efektem tej interpretacji jest ocena postaw historyków z okresu PRL, pewnego rodzaju „rozliczenie się” z tamtym okresem, oznaczające również zrozumienie tamtych postaw, ich egzystencjalne oswojenie, warunkujące rozumienie i rozstrzyganie naszych własnych dylematów, przed którymi stoimy współcześnie.

W rozumieniu Autora ocena postaw nie ma być jednak dokonywana z pozycji naukowej i moralnej wyższości krytyka nad krytykowanym, lecz powinna być wypracowywana w oparciu o rozumienie historycznych i aksjologicznych uwarunkowań, w jakich żyli i tworzyli historycy w minionym okresie. Rozumienie okoliczności zabezpiecza przed fundamentalistyczną krytyką o charakterze prokuratorskim (Stobiecki 2020: 18). Ocena zatem, do której Autor zmierza, nie jest oskarżeniem (formułowanym w horyzoncie możliwego potępienia), lecz rozumieniem ukierunkowanym na wypracowanie pomyślnego sposobu włączenia tradycji historiograficznej do współczesności. Jest zatem pewnym rodzajem interpretacyjnego wynajdowania (określania i kształtowania) tradycji obecnej w teraźniejszości.

Innymi kluczowymi pojęciami interpretacji Stobieckiego są wdzięczność i ostrzeżenie, wypowiadane przez Autora łącznie. Jest tak, ponieważ odnoszą się one zarówno do stosunku historyka historiografii (i reprezentowanej przez niego dzisiejszej wspólnoty badawczej historyków) do badaczy aktywnych w okresie PRL, jak i do postaw badaczy aktywnych w okresie PRL wobec nadzoru partyjno-państwowego. Z jednej strony, winniśmy im wdzięczność, gdyż od nich pochodzimy i w takim zakresie, w jakim oni oraz ich przykład nas ukształtował, pozostają częścią nas samych i naszej współczesności. Wyklucza to strategię zdystansowanego i chłodnego rozliczania z przyjmowanych postaw i domaga się podejścia powściągliwego, w wielu wypadkach wspaniałomyślnego, domaga się ujawniania ich postaw z powstrzymywaniem się od ocen o charakterze potępienia (jeśli potępienie nie jest w określonych przypadkach konieczne). Słowem, domaga się rozumienia połączonego z uznaniem zaciągniętego długu wdzięczności. 
Z drugiej jednak strony, jeśli weźmiemy pod uwagę współczesną, będącą naszym własnym losem, dzisiaj, presję na naukę historyczną ze strony czynników państwowych i transmitowanej przez nie ideologii, przyjrzenie się postawom naszych poprzedników może być dla współczesnych ostrzeżeniem przed zajmowaniem niektórych z możliwych postaw wobec nadzoru władzy ${ }^{4}$. Autor przestrzega przed uprawianiem historii historiografii w duchu fantazmatu nauki obiektywnej, niezaangażowanej aksjologicznie ${ }^{5}$. Analiza postaw historyków w okresie PRL jest cenna w jego perspektywie również właśnie współcześnie.

Oprócz szeregu rozstrzygnięć ściśle metodologicznych (trzy płaszczyzny tematyczne badań z zakresu historii historiografii, badanie postaw w kontekście nadzoru partyjno-państwowego, skoncentrowanie uwagi na historycznym losie środowiska historyków w okresie PRL), ta ostatnia perspektywa wydaje mi się kluczowa dla zrozumienia projektu badawczego analizowanej publikacji. Ponieważ współcześnie mamy do czynienia z próbami wywierania presji ze strony polityki na środowisko historyczne, w szczególności na historyków zajmujących się badaniami z zakresu historii najnowszej, potrzebna wydaje się próba dokonania bilansu historiografii PRL skupiająca się na postawach będących reakcją ówczesnych historyków na presję polityczną. Historiografia PRL... jest rozprawą Autora czującego się częścią humanistycznej inteligencji polskiej poddawanej presji charakterystycznej dla naszego własnego czasu i próbującego przyjrzeć się dylematom i wyborom naszych poprzedników, poddanych nadzorowi znacznie bardziej nasilonemu i brutalnemu, ale zachowującemu znamiona pewnej analogii do naszej aktualności. Koło hermeneutyczne w jego rozumowaniu jest dobrze widoczne. Stobiecki pozostaje w nim świadomie, by bronić wartości, jaką jest autonomia uniwersytetu i wolność badań naukowych. O wolność chodziło wówczas i o wolność oraz o zagrożenie bezdomnością toczy się gra dzisiaj. Podobieństwa między momentami w czasie (ulokowanie badacza i temporalne ulokowanie przedmiotu badania) czynią książkę Stobieckiego

4 Por. projekt Kodeksu Etyki Polskiego Towarzystwa Historycznego (http://pth.net.pl/ aktualnosci/250, dostęp: 30.08.2021) oraz dyskusję na łamach numeru tematycznego czasopisma Historia@Teoria zatytułowanego Dylematy Metodologiczne Historii Najnowszej (nr 6, 2017/4), w której na temat wyzwań analizowanych w artykule Jana Pomorskiego zabrali głos Ewa Solska, Wojciech Wrzosek, Rafał Stobiecki, Marek Woźniak, Mariusz Mazur, Hubert Łaszkiewicz oraz Robert Traba.

5 „Nie udawajmy, że istnieje historia «niewinna», pozbawiona zakorzenienia w aksjologii, «obiektywna», w rozumieniu naszych szacownych poprzedników z drugiej połowy XIX w. Powinniśmy sobie wyraźnie uświadomić, że to, jak postrzegamy siebie, jakich bronimy wartości, determinuje naszą wizję przeszłości” (Stobiecki 2020: 236). 
aktualną również w tym sensie, że nadają jej rolę lustra, w którym możemy przyjrzeć się, by zrozumieć nasze własne zmagania.

A jednak podczas lektury wzrastał we mnie, dyskretnie zaznaczający swoją obecność, dystans wobec niektórych aspektów metody przyjętej przez Autora. Historycy tamtego czasu pozostawali pod presją, którą Stobiecki syntetycznie określa nadzorem ze strony partii i państwa. Byli zmuszeni do toczenia gry o urządzenie się w polu społecznym, w sensie Pierre’a Bourdieu, o zachowanie tożsamości zgodnej z wyznawanymi wartościami i z etyką prowadzenia badań naukowych (Stobiecki 2020: 23). Wydaje mi się jednak, że moglibyśmy podejmować próby nieco większego uwypuklenia tego, co nazwałbym intencjonalnością ludzi żyjących i działających w tamtym czasie. Na podstawie rozważań Autora można nabrać przeświadczenia, że poza historykami intencjonalnie angażującymi się w budowę nowego ustroju i włączającymi się w kreowanie jego aspektu ideologicznego, większość historyków tworzących w tym czasie traktowała nadzór ze strony systemu jako nadzór czynników zewnętrznych, niekiedy przemożnych w tym sensie, że nie można się uchylić spod ich presji.

W powojennym środowisku polskich historyków ujawniła się cała paleta postaw. [...] Jego częścią byli historycy, których można określić mianem uosobienia doktryny (np. Żanna Kormanowa), „mistrzowie partyjnej mimikry" (określenie Stefana Mellera), jak choćby Henryk Jabłoński, zwolennicy „obrony substancji” (np. Aleksander Gieysztor), wreszcie badacze „niepokorni” (np. Henryk Wereszycki) (Stobiecki 2020: 243).

Wydaje się, że większość historyków odpowiadała (mniej lub bardziej) modelowi „obrony substancji” (lub solidaryzowała się z tym modelem) i starała się prowadzić badania naukowe, to znaczy wytwarzać prawdziwe (zgodne z respektowanymi regułami określającymi tożsamość nauki historycznej) obrazy przeszłości, na ile to było możliwe w warunkach, w jakich funkcjonowali. Oznacza to, że intencją historyków (ich, by użyć innej kategorii, intencjonalnością) było uprawianie badań historycznych zgodnie z uznawanymi przez siebie i ich środowiska badawcze regułami, a nadzór stanowił pewnego rodzaju przeszkodę w realizacji tak określonej intencjonalności. Historycy pragnęli badań bez nadzoru lub badań prowadzonych w warunkach nadzoru, lecz takich, na których rezultaty nadzór miał mieć wpływ minimalizowany, na ile to było możliwe.

Książka Stobieckiego o historiografii PRL oddaje znaczną część prawdy tamtego czasu, kiedy badania naukowe prowadzone były w warunkach presji państwa i partii. W konsekwencji, chcąc historiograficznie uchwycić działanie 
środowiska historiograficznego tego okresu, nie możemy abstrahować od politycznej presji na badania.

Zastanawiam się jednak - i jest to pytanie kogoś, kto uprawia teorię historii, a więc również poszukuje nieoswojonych jeszcze możliwości dla badań (choćby możliwości złudnych) - czy nie byłoby metodologicznie akceptowalne i pomyślne wypracowywanie obrazu przeszłości, który w ramach kreowanej w nim reprezentacji przeszłości uwalniałby ówczesnych historyków z tego, czego oni sobie nie życzyli, co było ich nieszczęściem. Tym samym ukazałby ich w większym stopniu, niż było ich udziałem w realnej historii, jako wolnych i w wolny sposób realizujących intencjonalność konstytuującą ich tożsamość badawczą. Zdaję sobie sprawę z tego, że moje słowa - na pierwszy rzut oka - mogą wywoływać konfuzję i niedowierzanie. Wymagają zatem uściślenia i wyjaśnienia.

Pierwszym założeniem powyższego pytania jest wzięcie pod uwagę, że los historyków z przeszłości (również historyków z okresu PRL) nie kończy się wraz z zakończeniem ich profesjonalnej aktywności lub wraz z ich śmiercią. Trwa ów los nadal w obejmujących ich obrazach pamięciowych lub historiograficznych, należą oni wciąż do historii, choć nie można już powiedzieć, że należą do niej jako jednostki żywe, świadome i działające. Czy formy istnienia po okresie aktywności lub po śmierci mają znaczenie? Dla niegdyś aktywnych i żywych - być może już nie. Inaczej jest zapewne w okresie między zakończeniem aktywności profesjonalnej a śmiercią, w którym dla historyka mogą być istotne obrazy ukazujące jego minioną aktywność, w których presja ze strony systemu w mniejszej mierze determinuje jego los, niż determinowała go w realnej historii, której nie można zmienić.

Modyfikacja obrazu przeszłości ukierunkowana na uwypuklenie intencjonalności podmiotów realnej historii (w tym przypadku historyków tworzących środowisko historiograficzne w okresie PRL), będąca świadomą redukcją całości realnej historii do jej fragmentu lub aspektu, posiada znaczenie z punktu widzenia dalszego toczenia się dziejów (w tym historii historiografii), dalszego, to znaczy mającego miejsce po okresie aktywności podmiotów historii ukazywanych w jej historiograficznym (zmodyfikowanym) obrazie. Historia toczy się nadal i by toczyła się pomyślnie, potrzebujemy nie tylko realnych obrazów przeszłości, ale również takich obrazów, które będą konstruowane wokół dawnych marzeń i oczekiwań, choćby nawet zostały one niegdyś obrócone w ruinę pod presją nadzoru przemożnych sił ${ }^{6}$.

6 Por. np. rozważania Paula Ricoeura na temat relacji między interpretacją przeszłości i obietnicami sformułowanymi w niej, lecz niewypełnionymi, niezrealizowanymi (Ricoeur 1985). 
Drugie przybliżenie sensu mojego przeświadczenia o potrzebie modyfikacji obrazu przeszłości powinno rozwiać nasuwającą się wątpliwość, wskazującą, że modyfikacja obrazu przeszłości wiąże się z jej fałszowaniem, jak np. wówczas, gdy miałby być w pewnym zakresie pominięty nadzór nad intencjonalnością historiograficzną, ten właśnie, który w toku realnej historii osaczał tę intencjonalność, niekiedy dosłownie w postaci agenturalnych donosów (Stobiecki 2020: 241). Nie sądzę, że tego rodzaju możliwy zarzut musi być trafny.

Zauważmy najpierw, że również Autor książki skupia się (tzn. dokonuje selekcji) na tym, w jaki sposób presja ze strony państwa starała się modelować badania historyczne i w jaki sposób historycy odnosili się do tej presji, przyjmując takie a nie inne wobec niej postawy, zróżnicowane i zależne od lokalnych i osobistych okoliczności, które historyk historiografii powinien brać pod uwagę (Stobiecki 2020: 18). Taka perspektywa wpływa na selekcję uwzględnianego materiału we wszystkich trzech branych pod uwagę przez Autora zakresach tematycznych tego rodzaju historii historiografii, jaki uprawia, podążając za swoimi mistrzami, Krystyną Śreniowską i Andrzejem Feliksem Grabskim.

$\mathrm{Na}$ poziomie instytucjonalnej organizacji pracy środowiska historyków w okresie PRL uwypuklone zostały w książce problemy związane z zarządzaniem historiografią przez państwo oraz powstawanie instytucji naukowych w obrębie PZPR, których zadaniem miało być sprawowanie ideologicznego monitoringu i nadzoru nad nauką uprawianą na uniwersytetach i w instytutach Polskiej Akademii Nauk. W zakresie oblicza teoretyczno-metodologicznego historiografii PRL Autor śledzi odniesienia historyków do marksizmu jako ideologii oraz teorii historii, a także spory w obrębie marksizmu między marksizmem ortodoksyjnym (wiązanym z postacią na przykład Adama Schaffa) i marksizmem rewizjonistycznym (w postaci na przykład rozważań metodologicznych Jerzego Topolskiego). W tym drugim kontekście (między innymi) rozpatrywana jest w książce dyfuzja do polskiej historiografii idei wypracowanych na gruncie francuskiej szkoły Annales. W zakresie wytworzonych przez historiografię PRL obrazów przeszłości Polski i reprezentacji historii powszechnej analizowane są przez Autora zaniechania i pominięcia, takie jak np. marginalizacja Polski jagiellońskiej, pomijanie historii tzw. Kresów Wschodnich, zafałszowania dotyczące stosunków polsko-radzieckich, ruchu socjalistycznego i robotniczego, deformacje dotyczące historii polskiej emigracji, szczególnie w XX wieku. Selekcja materiału w książce i kąt jego oświetlenia wynika ze skupienia uwagi Autora na nadzorze partyjno-państwowym nad historiografią oraz na postawach i strategiach historyków odniesionych do tego nadzoru. Selekcja jest zawsze redukcją materiału badawczego do jego określonych aspektów. 
Ponadto spróbujmy w tym rozważaniu wziąć pod uwagę znaną teoretykom poznania historycznego opozycję wypracowaną przez Michela de Certeau między strategiami i taktykami (de Certeau 1990). Te pierwsze charakteryzują aktywność systemu nadzorującego i dyscyplinującego podlegające mu grupy społeczne. Na niej skupia się dorobek Michela Foucalta, szczególnie dzieło Nadzorować i karać, i wiąże ją z metaforą panoptykonu (Foucault 1920). Taktyki w ujęciu de Certeau to reakcje podporządkowywanych (polegające na zastosowaniu pewnego rodzaju sprytu czy przebiegłości praktycznej), których sensem jest uchylenie się spod presji praktyk strategicznych. Podporządkowywani wymykają się podporządkowującym ich strategiom, gdyż potrafią w zastanych warunkach (określonych przez praktyki strategiczne) realizować własne cele, różne od wyznaczanych przez panoptykon.

Historycy polscy w okresie Polski Ludowej nie tylko reagowali (taktycznie) na strategie partii i państwa, nie tylko byli kształtowani przez warunki działania. Pomimo nadzoru potrafili realizować własne cele, będąc zdolnymi do repliki własnych taktyk w stosunku do strategii władzy. Odpowiedź tego rodzaju nie miała jednak charakteru frontalnej konfrontacji z działającymi strategicznie, lecz zasadzała się na pewnego rodzaju uchylaniu się i realizowaniu własnych celów w przestrzeni pozostającej mniej lub bardziej poza spojrzeniem i kontrolą podmiotów działań strategicznych.

Wydaje się, że jest możliwa jasna, by tak ją określić, interpretacja dokonań historyków, którym przyszło żyć i tworzyć w okresie PRL. Spójrzmy np. na moją własną macierzystą dyscyplinę badawczą, jaką jest inicjowana w Polsce przez Topolskiego metodologia historii. Projekt metodologiczny Topolskiego daje się, jeśli zechcemy, interpretacyjnie zamknąć w szufladce marksizmu rewizjonistycznego, jeśli jest - jak czyni to Autor - rozpatrywany w ramach relacji między metodologiami praktycznymi fundującymi prace historyków w okresie PRL a ideologią marksistowską narzucaną przez strategie podejmowane przez system. Jeśli jednak spojrzymy na ów projekt, nie ograniczając się do relacji między strategiami systemu i reakcjami postaw historyków na te strategie, okaże się, że pełniejszy jest obraz, który przedstawia metodologię Topolskiego jako próbę modernizacji historiografii poprzez nasycenie jej różnego rodzaju treściami teoretycznymi, próbę w udany sposób kontynuującą niektóre elementy dorobku szkoły lwowsko-warszawskiej w teorii poznania naukowego (poprzez nawiązania do dorobku Kazimierza Ajdukiewicza i innych). Topolski projektował przełom metodologiczny w historiografii, chcąc zbliżyć ją do nauk społecznych i nauk o kulturze. Zamykanie go w formule marksizmu rewizjonistycznego jest wprawdzie trafne z perspektywy przyjmowanej przez Autora książki (w której postawy są reakcją na nadzór), jednak redukuje ona 
bogactwo projektu autora Metodologii historii i Teorii wiedzy historycznej, gdyż jest w znacznej mierze zawężona do tego, co widać, gdy się bada relację między nadzorem i reakcjami na nadzór.

Podobne rozumowanie można przeprowadzić odnośnie do innych specjalności historiograficznych związanych z epokami historycznymi lub problemowym podziałem pracy w obrębie historiografii. Wszędzie tam historycy pisali książki i artykuły odkrywające przeszłość, niekoniecznie sprowadzalne w swoich istotnych wymiarach do relacji między środowiskiem historyków i władzą. Nadzór nie wszędzie wnikał w badania i nie dla wszystkich badań miał znaczenie.

Wydaje się, że uwypuklanie we współczesnych badaniach z zakresu historii historiografii dawnego nadzoru partii i państwa, choć pozwala na ukazanie istotnych okoliczności badań historiograficznych uprawianych w analizowanej epoce, w niektórych przypadkach wiąże się utraceniem z pola widzenia tego dorobku historiografii lub tych aspektów owego dorobku, które dzięki uruchamianym przez historyków taktykom wymykały się nadzorowi w sensie stanięcia gdzie indziej i podjęcia czynności, których nie dotyczył atak strategii systemu?

Zdaję sobie sprawę z tego, że takie stanowisko może napotkać opór ze strony Czytelnika. Sądzę jednak, że powinniśmy podejmować wysiłki interpretacyjne zmierzające do skonstruowania możliwie adekwatnych obrazów przeszłości, takich jednak, które szukają możliwości pokazania historyków polskich drugiej połowy XX wieku poza presją lub obok presji przychodzącej od systemu politycznego, a w każdym razie nie redukują ich w znacznej mierze do reakcji na presję. Rozpatrywanie praktyk wyłącznie lub przede wszystkim w kontekście nadzoru partyjno-państwowego wydaje mi się po latach symbolicznym zwycięstwem nadzorcy nad nadzorowanym. W wytwarzanym w ten sposób dzisiaj obrazie przeszłości wciąż dominuje zewnętrzna, pozanaukowa, polityczna siła sięgająca swymi oczekiwaniami do gruntu postaw historyków i wytworów ich pracy badawczej. Chciałbym, żebyśmy próbowali dostrzec niesprowadzalność postaw i rezultatów badań do perspektywy akcentującej relację władza vs. środowisko historyków. Właśnie wówczas pełniej zrozumiemy, w jaki sposób nadzorowani odnosili - nauczmy się stosować to słowo w tym kontekście zwycięstwo nad nadzorującymi. Podziwiam namysł Autora nad złożonością relacji między nami i naszą tradycją historiograficzną, złożonością wyrażającą

7 Zob. przykład bizantynologii na Uniwersytecie Łódzkim, którą łatwiej byłoby ująć w reprezentacji oferowanej w recenzowanej książce, gdyby była ona w nieco mniejszym stopniu determinowana przez jej generalną ramę interpretacyjną (zob. Stobiecki 2020: 248). 
się w napięciu, które zauważam, między „wdzięcznością” i „ostrzeżeniem”. Mając świadomość tego napięcia, zadaję sobie pytanie, czy bardziej powinniśmy odczuwać wdzięczność, czy przyjmować z przeszłości lekcję ostrzeżenia. Wydaje się, że Autor kładzie nacisk na ostrzeżenie, wskazując na potrzebę rozliczenia się z przeszłością i na ocenę postaw. Ja jednak, nie zapominając o ostrzeżeniu, skupiam bardziej uwagę na wdzięczności, gdyż w jej świetle można pełniej ukazać dokonania naszych poprzedników i ich zwycięstwa nad figurami próbującymi ich podporządkować. Odsłaniajmy nie tyle heroiczną, lecz po prostu jasną stronę ich osiągnięćs. Właśnie ona może stać się efektywnym wsparciem w zmaganiach z presjami aparatu, jakim poddawane są nasze pokolenia ${ }^{9}$.

8 Zob. Śreniowska 2018. Autorka, Mistrzyni Rafała Stobieckiego, uczy we wspomnieniach, w jaki sposób interpretować ludzkie postawy w sposób rozumiejący ich historyczne uwarunkowania. Por. np. następujące fragmenty: „Wszyscy, niezależnie od orientacji politycznej, chcieli się jakoś odnaleźć w nowej rzeczywistości. Któż miał ją budować, jeśli nie Polacy mieszkający nad Wisłą i Odrą. Żadna emigracja nigdy nie jest w stanie dźwignąć kraju z gruzów, zadbać, by instytucje funkcjonowały, by nasza młodzież się kształciła itd. Dziś wytykanie literatom, że wówczas chcieli zaistnieć, wytykanie młodym uczonym, że pragnęli uporządkować swoje życie, przekazać zdobytą wiedzę, to wszystko zarzuty nieliczące się z realiami tamtego czasu. [...] Nasze pokolenie, dotkliwie doświadczone już przed wojną (nadprodukcja inteligencji) i w czasie wojny płacące wysoką cenę za przynależność do inteligencji, świadomej warstwy narodu, jest krzywdzone zarzutami, które się obecnie, na fali rozrachunku z przeszłością komunistyczną, dokonywa" (Śreniowska 2018: 129-130).

9 Tego rodzaju wsparcie byłoby jedną z postaci dialogu międzypokoleniowego, kształtowaniu którego ma w intencji Autora służyć Historiografia PRL...; książka ta „wyrasta z idei niezbędnego dialogu międzypokoleniowego, w tym wypadku dotyczącego środowiska historyków w epoce PRL i szacunku dla historiograficznej tradycji. W zamierzeniu autora ma służyć zrozumieniu, a co za tym idzie - wyjaśnieniu zachodzących w niej przemian (Stobiecki 2020: 236). 


\section{| Bibliografia}

Certeau de Michel (1990), L'invention du quotidien, t. 1: Arts de faire, Édition de

Luce Giard, Nouvelle édition, Gallimard, Paris.

Foucault Michel (1920), Nadzorować i karać. Narodziny więzienia, przeł. Tadeusz

Komendant, Wydawnictwo Aletheia, Warszawa.

Ricoeur Paul (1985), Temps et Récit, t. III, Seuil, Paris.

Stobiecki Rafał (2020), Historiografia PRL. Zamiast podręcznika, Wydawnictwo

Uniwersytetu Łódzkiego, Łódź.

Śreniowska Krystyna (2018), Moje życie, oprac., wstęp i komentarz Jolanta Kol-

buszewska, Rafał Stobiecki, Wydawnictwo Uniwersytetu Łódzkiego, Łódź.

\section{| Abstrakt \\ Maciej Bugajewski \\ Wdzięczność i ostrzeżenie? Rozważanie metodologiczne o nowej próbie bilansu historiografii PRL}

W niniejszym artykule podejmuję próbę lektury nowej monografii dotyczącej historiografii w okresie PRL napisanej przez Rafała Stobieckiego. Kluczowymi pojęciami książki są - w mojej opinii - wdzięczność i ostrzeżenie, wypowiadane łącznie. Autor pracuje w oparciu o szerokie rozumienie zakresu badań historii historiografii. Obejmuje on interpretacją nie tylko (1) „badania nad infrastrukturą nauki historycznej”, do których zalicza instytucjonalny wymiar środowiska historyków, lecz również (2) przemiany założeń metodologicznych, na których były oparte badania historyczne w okresie PRL oraz (3) zasadnicze cechy reprezentacji przeszłości wypracowanych przez historiografię PRL. Autor książki kładzie nacisk na ostrzeżenie, wskazując na potrzebę oceny postaw historyków. Ja jednak skupiam uwagę na wdzięczności, bo w jej świetle można ukazać dokonania naszych poprzedników i ich zwycięstwa nad figurami próbującymi ich podporządkować.

Słowa kluczowe: historiografia, PRL, strategie, taktyki, obietnica 


\section{| Abstract \\ Maciej Bugajewski \\ Gratitude and Warning? Methodological Considerations on a New Attempt to Balance the Historiography of the People's Republic of Poland}

In this article, I attempt to read a new monograph on historiography in the communist period, written by Rafał Stobiecki. The key concepts of the book are - in my opinion - gratitude and warning, spoken together. The author works on the basis of a broad understanding of the scope of research in the history of historiography. The author interprets not only (1) "research on the infrastructure of historical science", which includes the institutional dimension of the historians' milieu, but also (2) changes in the methodological assumptions on which historical research was based during the Polish People's Republic and (3) the essential features of the representation of the past developed by the historiography of the People's Republic of Poland. The author of the book emphasizes the warning, pointing to the need to evaluate the attitudes of historians. However, I focus my attention on gratitude, because it shows the achievements of our predecessors and their victories over the figures trying to subjugate them.

Keywords: historiography, PRL, strategies, tactics, promise

\section{| Biogram}

Maciej Bugajewski - dr hab., prof. UAM, pracuje na Wydziale Historii UAM. Zajmuje się zagadnieniami metodologii historii, historii historiografii, teoretycznymi problemami pamięci historycznej. Wybrane publikacje: Brzemię przeszłości. Zło jako przedmiot interpretacji historycznej (2009); Historiografia i czas. Paula Ricoeura teoria poznania historycznego (2002); Czy przeszłość powinna być inna? Studia $z$ teorii $i$ historii historiografii (red., 2008); Współczesna francuska historia kobiet. Dokonania - perspektywy - krytyka (wraz z M. Solarską, 2009); „Sensus Historiae" 4/2011 oraz 1/2012 (numery tematyczne poświęcone pamięci historycznej; red. naukowa wraz z I. Skórzyńską); „Rocznik Antropologii Historii” nr 1, 2013 (O Reprezentacji; red. naukowa wraz z V. Julkowską); Doświadczanie przeszłości. Poznanie historyczne wobec pluralizmu czasu historycznego (2018, wraz z M. Solarską) Historyczna wspólnota słowa. Rozważanie z teorii historii (2018); redaktor naukowy (wraz z V. Julkowską i M. Solarską) dwóch tomów czasopisma Teoria@Historia o problemach historii historiografii (2017 i 2018).

E-mail: maciej.bugajewski@amu.edu.pl

ORCID: 00oo-0003-4016-917X 